\title{
A FELSŐFOKÚ KÉPZÉS BEFEJEZÉSÉRE IRÁNYULÓ SZÁNDÉK ELŐREJELZŐI ${ }^{+}$
}

\author{
CZAKÓ ANDREA ${ }^{a, *}$ - NÉMETH LILLA ${ }^{a, b}-$ FELVINCZI KATALIN ${ }^{a}$ \\ ${ }^{a}$ ELTE PPK Pszichológia Intézet \\ ${ }^{\text {b} E L T E ~ P P K ~ P s z i c h o l o ́ g i a i ~ D o k t o r i ~ I s k o l a ~}$
}

Kutatásaink során arra teszünk kísérletet, hogy megalkossuk a felsőfokú képzés befejezésére irányuló szándéknak, illetve a képzés tényleges elvégzésének prediktív modelljét. Megvizsgáltuk, hogy az egyetemi képzés első két félévére vonatkozó, a tanulmányi rendszerből elérhető előmeneteli és személyes adatok, illetve online kérdőíves vizsgálataink során feltárt pszichológiai sajátosságok, motivációs változók, továbbá a képzéssel való elégedettség közül melyek bizonyulhatnak hasznosnak a felsőfokú képzés végzettség nélkül történő félbehagyásának elörejelzésében. Vizsgálatunk kiterjedt a képzés befejezésére irányuló szándék és a képzés folytatásával potenciálisan összefüggő szocioökonómiai tényezők elemzésére is.

Kulcsszavak: tanulmányi sikeresség, felsőfokú képzésben való bennmaradás, pszichológiai háttérváltozók

In our researches we have aimed to create predictive models of academic success and intention to persist in a higher education program. Several administrative data - both individual and educational - from the first two semesters of university education together with numerous other variables (such as psychological and motivational factors, and satisfaction with the training) were analyzed in order to assess which of these could be useful in predicting academic success or failure (dropout) in the course of higher education training program. Socioeconomic variables that were supposed to correlate with the intention of accomplishing higher education program were also analyzed.

Keywords: academic success, higher education retention, psychological variables

A tanulmány az EFOP 3.4.3-16-2016-00011 jelü (A felsőoktatás hozzáférhetőségének javítása, komplex, fenntartható tanulásttámogatási környezet kialakítása, az oktatás innovatív megújítása az ELTE telephelyein) projekt anyagi támogatásával jött létre.

* Levelező szerző: Czakó Andrea, ELTE PPK, 1075 Budapest, Kazinczy u. 23-27.

E-mail: czako.andrea@ppk.elte.hu 


\section{Bevezetés}

leggyakrabban lemorzsolódásként definiált, a felsőfokú képzés végzettség nélkül
történő megszakadása mind az egyén, mind a felsőoktatási intézmények, mind
a társadalom szintjén számos problémát vet fel. Bár 2005 és 2015 között a felsőfokú képzést kezdők aránya az OECD-országok többségében emelkedett (OECD 2017), az azt félbehagyók aránya nem mérséklődött, így mára a képzettségi szint növelésének érdekében a felsőoktatási bemenet szélesítése mellett a kimeneti sikeresség támogatása is egyre sürgetőbbé vált.

A problémakör hazai nagyságrendjét érzékelteti, hogy a Felsőoktatási Információs Rendszer adatai szerint a 2009/2010-es tanévben az alapképzésüket megkezdő hallgatók közül 2014 tavaszáig minden harmadik az abszolutórium megszerzése nélkül hagyta félbe képzését (Stéger 2015).

Tekintettel arra, hogy a lemorzsolódásnak jelenleg nincsen nemzetközileg vagy akár országosan egységesen elfogadott definíciója, és a jelenség számos szinten értelmezhető - sőt hazánkban felmerül egy speciális szempont is, annak kérdése, hogy azokat a hallgatókat, akik esetében az abszolutóriumot ${ }^{1}$ nem követte a diploma megszerzése, lemorzsolódónak tekinthetjük-e -, ezek közül a témával kapcsolatos felmérések során a kutatók az adott felmérés céljainak és részben az elérhető adatoknak leginkább megfelelő definíciót használják elemzéseik során. A jelen tanulmányban ismertetett kutatásainkban a tanulmányok sikeres folytatását és a felsőoktatási lemorzsolódást minden esetben a képzések szintjén ragadtuk meg: azt vizsgáltuk, hogy egy adott időpontban felsőfokú képzést kezdő hallgatók közül kik azok, akik ezt a megkezdett képzést sikeresen folytatják, vagyis a felmérés nem terjedt ki a képzés-, és intézményváltók vizsgálatára, illetve a képzés félbehagyását követő tanulmányi életútra. Sikeresként a legalább az abszolutóriumot megszerző volt hallgatókat kategorizáltuk. A kutatások fókuszában egyetlen felsőoktatási intézmény, az Eötvös Loránd Tudományegyetem hallgatói álltak.

$\mathrm{A} z$ itt bemutatott felmérések kidolgozása során egyrészt saját korábbi kutatásaink (Czakó 2017; Czakó-Bolló 2017) eredményeire támaszkodtunk, másrészt felhasználtuk Vincent Tinto elméleti, intézményi modelljét (Tinto 1975), amit számos szerző közel paradigmatikusnak tekint a lemorzsolódás kutatásában (Braxton et al. 2014; DavidsonWilson 2013). Ezen elmélet szerint elsősorban a hallgatók társas és egyetemi integrációjának („social and academic integration”) erőssége határozza meg a hallgatók elköteleződését az intézményben való bennmaradás és diplomaszerzés mellett, ami a képzés félbehagyására irányuló döntésüket formálja. Az integrációt a hallgatók személyes és szocioökonómiai jellemzői, korábbi tanulmányaik, az egyetemmel kapcsolatos kezdeti elvárásaik és az egyetem akadémiai és társas színterein szerzett tapasztalataik egymásra ható tényezői alakítják. Vizsgálataink során a képzés első tanévére koncentráltunk, mivel a felsőoktatási lemorzsolódások időbeli mintázatából kitűnik, hogy a hallgatói sikeresség szempontjából ennek az időszaknak kiemelt jelentősége van: ez az év alapozza meg

\footnotetext{
Végbizonyítványt vagy abszolutóriumot a felsőoktatási intézmény annak a hallgatónak állít ki, aki a tantervben elöírt krediteket megszerezte, és teljesítette a számára előírt szakmai gyakorlatot (2011. évi CCIV. törvény a nemzeti felsőoktatásról, 2011). Az abszolutórium kiállításának nem feltétele a diplomához szükséges nyelvvizsga megléte, illetve a szakdolgozat elkészítése és megvédése.
} 
a későbbi egyetemi sikerességet és bennmaradást, és nem véletlen, hogy a lemorzsolódás mértéke is az első évben a legmagasabb (Reason-Terenzini-Domingo 2006; Stéger 2015).

Tanulmányunkban két felmérés eredményei alapján arra keressük a választ, hogy

1. melyek azok, a már az alapképzés korai szakaszában - vagyis annak első két félévében - a tanulmányi rendszerből elérhető, a tanulmányi életútra, a hallgató személyes hátterére és a képzés jellemzőire vonatkozó adatok, melyek a képzés elvégzésének sikerességével kapcsolatban vannak? (1. vizsgálat)

2. a tanulmányi és személyes háttérváltozókon kívül melyek lehetnek az ezeket a változókat kiegészítő, a lemorzsolódással potenciálisan kapcsolatban álló pszichológiai, motivációs és egyéb háttérváltozók? (2. vizsgálat)

\section{Módszertani áttekintés}

A jelen tanulmányban két kutatás első eredményeit ismertetjük, melyek közül az egyikben (1. vizsgálat) tanulmányi adatokat vizsgáltunk, míg a másik (2. vizsgálat) elsőéves hallgatók körében lebonyolított online kérdőíves adatfelvétel adatainak elemzéséből állt. A felmérések főbb paramétereit az 1. táblázat tartalmazza, a módszertanra bővebben az egyes vizsgálatok bemutatásánál térünk ki.

1. táblázat: A tanulmányban bemutatott felmérések összefoglaló adatai

\begin{tabular}{|c|c|c|}
\hline & 1. vizsgálat & 2. vizsgálat \\
\hline Módszertan & $\begin{array}{l}\text { Anonim tanulmányi adatok } \\
\text { elemzése }\end{array}$ & $\begin{array}{l}\text { Online kérdőíves kutatás, tanul- } \\
\text { mányi adatokkal összekapcsolva }\end{array}$ \\
\hline Résztvevők & $\begin{array}{l}\text { Az ELTE-re 2012-ben, 2013- } \\
\text { ban és 2014-ben magyar nyelvü } \\
\text { alapképzésre felvételt nyert, majd az } \\
\text { intézménybe beiratkozó hallgatók }\end{array}$ & $\begin{array}{l}\text { Azok az ELTE-re 2018-ban alap- } \\
\text { vagy osztatlan képzést aktív félévvel } \\
\text { kezdő hallgatók, akik a felmérés } \\
\text { online kérdőívét kitöltötték }\end{array}$ \\
\hline Résztvevők létszáma & 16302 fö & 1515 fö \\
\hline $\begin{array}{l}\text { Adatgyüjtés } \\
\text { időpontja }\end{array}$ & 2018. szeptember & $\begin{array}{l}\text { Kérdőíves: 2018. november, Tanul- } \\
\text { mányi adatok: 2019. szeptember }\end{array}$ \\
\hline Függő változó & $\begin{array}{l}\text { Tényleges lemorzsolódás (abszolu- } \\
\text { tórium megszerzése vagy a } \\
\text { megkezdett képzés abszolutórium } \\
\text { nélkül történő félbehagyása } 2018 \\
\text { szeptemberében) }\end{array}$ & $\begin{array}{l}\text { 1. A képzés befejezésére irányuló } \\
\text { szándék } \\
\text { 2. 2019. szeptemberi tanulmányi } \\
\text { státusz (még hallgató, illetve lemor- } \\
\text { zsolódott, vagy második féléve } \\
\text { passziv) }\end{array}$ \\
\hline Független változók & $\begin{array}{l}\text { Tanulmányi és felvételi eredmé- } \\
\text { nyek, lakóhely településtípusa, nem, } \\
\text { kollégiumi lakhatás, szociális támo- } \\
\text { gatás, képzés alapvető jellemzői }\end{array}$ & $\begin{array}{l}\text { Demográfiai és képzéssel kapcsola- } \\
\text { tos változók, motivációs változók, } \\
\text { képzéssel való elégedettség, } \\
\text { pszichológiai háttérváltozók, észlelt } \\
\text { tanulási kompetencia }\end{array}$ \\
\hline
\end{tabular}

A bemutatott elemzések során módszertani, illetve hozzáférhetőségi okokból három, némiképp eltérő függő változót használtunk, melyek részben a képzés folytatásának tényleges sikerességére, részben a képzés befejezésére irányuló szándékra vonatkoztak: 
1. A tanulmányi adatok elemzése során a (legalább) abszolutóriumot megszerző hallgatók csoportját hasonlítottuk össze a vizsgált képzést a végzettség megszerzése nélkül elhagyókkal (tényleges lemorzsolódás) (1. vizsgálat).

2. A kérdőíves kutatásban felmértük a képzés befejezésére irányuló szándékot (2. vizsgálat). Ezen szándék és a tényleges lemorzsolódás közti korreláció mértéke a nemzetközi szakirodalom szerint jelentős, a lemorzsolódási szándék a későbbi tényleges lemorzsolódás egyik megbízható elörejelzője (Bean 1980; Berger-Braxton 1998; CabreraNora-Castaneda 1992; Vallerand-Fortier-Guay 1997). Bár ennek az összefüggésnek a magyar mintán való igazolásával jelen tanulmány szerzői még nem találkoztak, jelen kutatás ennek az ellenőrzésére is lehetőséget biztosít majd.

3. A kérdőíves vizsgálatban részt vevő, 2018 őszén alapképzést kezdő hallgatók 2019. szeptemberi, a képzésre vonatkozó státuszának függő változóként való használatára is volt lehetőségünk. Itt sikertelenként definiáltuk a képzést ekkorra végzettség nélkül elhagyókat, illetve az egybefüggően második passzív félévüket kezdőket (képzést szüneteltetők), és sikeresként azokat, akik továbbra is aktív hallgatói képzésüknek, vagy már be is fejezték azt (2. vizsgálat).

\section{A lemorzsolódás korai előrejelzői a tanulmányi rendszer adatai alapján}

\section{Módszer}

Első vizsgálatunk az Eötvös Loránd Tudományegyetemre 2012-ben, 2013-ban és 2014ben magyar nyelvü alapképzésre felvételt nyert, majd az intézménybe beiratkozó hallgatók 2018. évi, a tanulmányi rendszerből származó tisztított anonim adatainak elemzésére irányult. Az adatokat adattisztítást és konvertálást követően Microsoft Excel program és IBM SPSS Statistics 25 statisztikai program segítségével elemeztük. A két csoport közti különbségek feltárására $\chi^{2}$ próbát és független mintás $t$-próbát alkalmaztunk, illetve a lemorzsolódás-sikeresség kétértékü függőváltozójának esélyhányadosainak becslésére bináris logisztikus regressziós magyarázó modellt építettünk.

\section{Eredmények}

A vizsgált években képzést kezdő, összesen 17575 főből az elemzésbe azon 16032 volt hallgató adatait vontuk be, akik esetében a képzés eredményessége az adatgyüjtés időpontjában biztosan meghatározható volt - vagyis azokat, akik már sikeresen eljutottak legalább az abszolutórium megszerzéséig (9939 fö; 62,0\%), és azokat, akiknek a képzése megszakadt (6903 fö; 38,0\%).

A képzések megszakadásakor a tanulmányi ügyintézők rögzítik annak okát a tanulmányi rendszerben, mely okok alapvetően négy nagyobb csoportba sorolhatóak: 1) anyagiak, vagyis vagy fizetési hátralék, vagy költségtérítés nem vállalása átsoroláskor; 2) tanulmányiak, vagyis (leggyakrabban) a képzési kötelezettség nem teljesítése; 3) saját kérésre történő elbocsátás és 4) sorozatos passziválásból eredő, vagyis a képzés megengedettnél hosszabb szüneteltetése. Ez utóbbi kettő az, ami leginkább feltételezi azt, hogy a hallgató meghozta a képzés félbehagyására irányuló döntését, amit vagy bejelentett, vagy megvárta, hogy passzivitása következtében a jogviszonya megszünjön. A vizsgált három évfolyamban a félbehagyott képzések megszakadásának oka 8,6\%-ban anyagi 
volt, 33,7\%-ban tanulmányi, 31,8\%-ban az ismétlődő passziválás, míg 25,9\%-ban a képzés a hallgató saját kérésére szakadt meg.

\section{A képzés jellemzői}

Ahogyan azt más kutatások és adatelemzések is kimutatták (pl.: Stéger-Demcsákné Ódor 2015) a vizsgált intézményben is jellemző volt, hogy a képzést sikeresen elvégzők aránya az informatikai és természettudományi alapképzések hallgatói körében volt a legalacsonyabb, míg a művészetközvetítési, pedagógusképzési és társadalomtudományi képzéseken a legmagasabb.

A tagozatot és finanszírozási formát tekintve a nappali és levelező tagozatos képzéseken tanulók összességében sikeresebbek voltak (63,0\%, illetve 61,3\%) az esti tagozaton tanulóknál ( $24,2 \%$ sikeres) $\left(\chi^{2}=221,1, \mathrm{~d} f=2, p<0,001\right)$, illetve az államilag támogatott képzések hallgatói nagyobb arányban szereztek diplomát az önköltséges finanszírozási formában tanulóknál $\left(64,4 \%\right.$ vs. 55,5\%) $\left(\chi^{2}=104,9, \mathrm{~d} f=1, p<0,001\right)$. A lemorzsolódási/ sikerességi rátákat a tagozatok és finanszírozási formák kombinációjában a 2. táblázat tartalmazza.

2. táblázat: Az ELTE-re 2012 és 2014 között alapképzésre felvett hallgatók tanulmányi sikeressége tagozat és finanszírozási forma szerinti bontásban

\begin{tabular}{llccc}
\hline Tagozat & Finanszírozási forma & Lemorzsolódott & Sikeres & Összes fö \\
\hline Nappali & Államilag támogatott & $35,2 \%$ & $64,8 \%$ & 10653 \\
Levelező & Államilag támogatott & $37,9 \%$ & $62,1 \%$ & 997 \\
Levelező & Költségtérítéses & $39,4 \%$ & $60,7 \%$ & 1268 \\
Nappali & Költségtérítéses & $43,1 \%$ & $56,9 \%$ & 2741 \\
Esti & Államilag támogatott & $63,9 \%$ & $36,1 \%$ & 36 \\
Esti & Költségtérítéses & $77,1 \%$ & $22,9 \%$ & 319 \\
\hline Összesen & & & $\mathbf{1 6 0 1 4}$ \\
\hline
\end{tabular}

Szociodemográfiai háttérváltozók

A nemeket összehasonlítva a nők szinte minden képzési területen nagyobb arányban fejezték be képzésüket: az összes hallgatót megvizsgálva a nők 30,5\%-os lemorzsolódási arányával összevetve a férfiak sikertelenségi rátája $51,4 \%$-os volt $\left(\chi^{2}=679,5, \mathrm{~d} f=1, p<\right.$ 0,001). Különösen kiugró volt a férfiak és nők közti különbség a pedagógus alapképzéseken, ahol a férfiak 55,5\%-a, míg a nők 24,7\%-a nem fejezte be a képzését, míg egyedül a természettudományi képzési területen nem volt szignifikáns eltérés a nők és férfiak sikertelenségi rátájában (47,5\%, illetve 47,9\%).

A fiatalabb hallgatók összességében nagyobb valószínüséggel fejezték be képzéseiket: alapképzésen a lemorzsolódók átlagos életkora a képzés kezdésének évében 22,6 év volt $(\mathrm{SD}=5,40)$, amíg a képzést sikeresen elvégzők átlagosan egy évvel fiatalabbak 21,6 évesek $(\mathrm{SD}=5,38)(t=11,821, \mathrm{~d} f=15904, p<0,001)$. Munkarendenkénti bontásban vizsgálva ugyanakkor látható, hogy az életkor ilyen irányú kapcsolata a sikerességgel a nappali tagozaton tanuló hallgatók csoportjában mutatható ki, ahol a lemorzsolódók életkora 
21,2 év ( $\mathrm{SD}=3,39)$, a sikereseké 20,0 év ( $\mathrm{SD}=2,04)(t=24,706, \mathrm{~d} f=13297, p<0,001)$. $\mathrm{A} z$ esti tagozaton nem volt szignifikáns korkülönbség a két csoport között, míg a levelező tagozaton a sikeres hallgatók átlagéletkora magasabb volt $(30,7$ év, $\mathrm{SD}=8,67)$, mint a lemorzsolódottaké (29,3 év, SD = 8,15).

$\mathrm{A} z$ állandó lakóhely településtípusa (főváros, megyeszékhely, város, község) alapján létrehozott csoportok között csekély mértékü volt az eltérés $\left(\chi^{2}=10,641, \mathrm{~d} f=3, p=\right.$ 0,014), ami nem tükrözi a települések hierarchiasorrendjét: a lemorzsolódási ráta a fóvárosiaknál 39,8\% ( $n=4978)$, a megyeszékhelyen élőknél: 37,4\% $(n=2959)$, a városiaknál: 36,7\% ( $n=4552)$, a községben élőknél: 37,6\% $(n=3051)$ volt.

\section{Kollégium, szociális támogatás}

A kollégium pozitív hatását jelzi, hogy a kollégiumban élő 3588 fő $86,8 \%$-a szerzett diplomát, szemben a kollégiumban nem élő 12318 fő 54,7\%-os diplomaszerzési arányával. Ez az eredmény annak fényében is különösen jelentős, hogy a kollégiumba történő felvételnél a kedvezőtlen szociális helyzetű hallgatók előnyt élveznek, és jelzi, hogy az egyetemi bevonódásnak, a hallgatók által észlelt támogatásnak fontos szerepe lehet a tanulmányok folytatásában. Ez a kapcsolat akkor is kimutatható, ha csak az államilag támogatott képzésben tanuló, nappali tagozatos hallgatók sikerességét vetjük össze kollégiumi elhelyezés szerinti bontásban (lásd az alábbi, 1. ábrán).

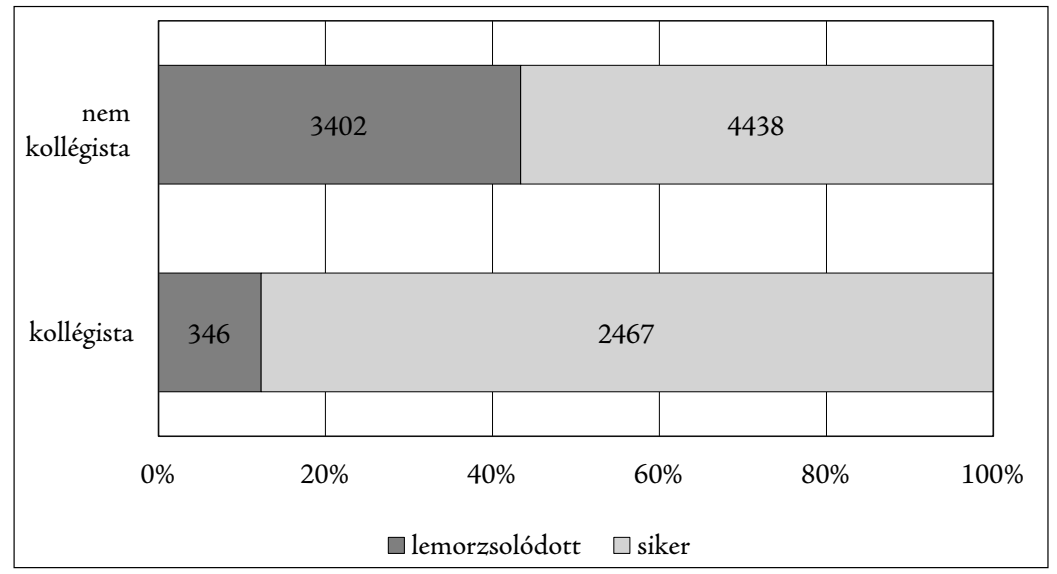

1. ábra: Az ELTE-re 2012 és 2014 között magyar nyelvű alapképzésre felvett, nappali tagozatos, államilag támogatott képzésben tanuló hallgatók $(n=10653)$ képzési sikeressége kollégiumi lakhatás szerinti bontásban

Eredményeink szerint az első félévben igényelt és megkapott szociális támogatástól függően is eltér a képzésüket sikerrel befejezők aránya: a képzésüket államilag támogatott finanszírozási formában kezdők közül az első félévben szociális támogatásban részesülő 2860 hallgató 28,7\%-a morzsolódott le, szemben az első félévben szociális támogatást nem kapó hallgatók 8404 fös csoportjával, akik közül 35,6\% nem végezte el sikeresen a képzését $\left(\chi^{2}=44,642, \mathrm{~d} f=1, p<0,001\right)$, ami szintén az egyetemi hallgatók számára biztosított támogatás kiemelt fontosságára hívja fel a figyelmet. 


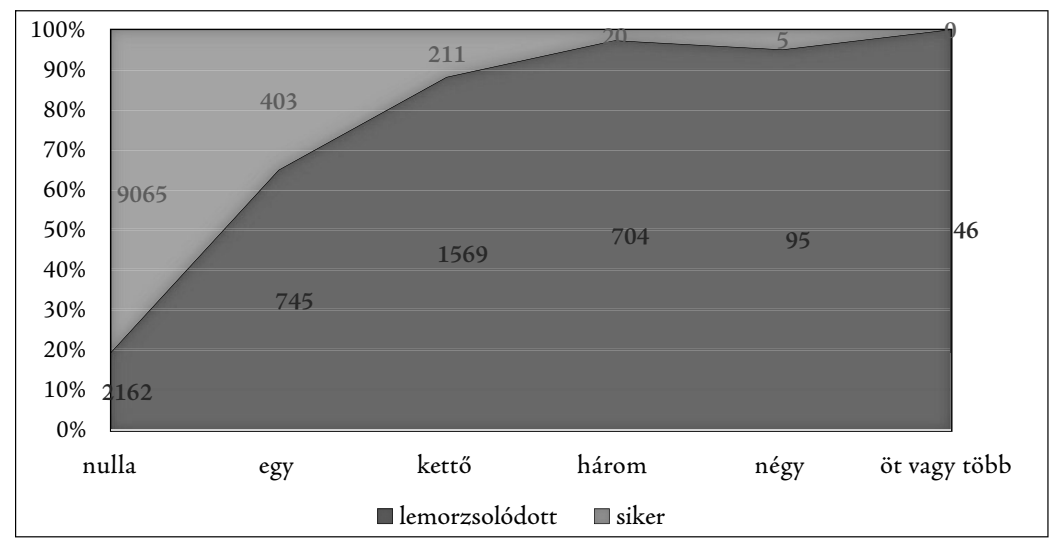

2. ábra: Az ELTE-re 2012 és 2014 között alapképzésre felvett és képzésüket aktív félévvel kezdő hallgatók képzési sikeressége a későbbi passzív félévek száma szerinti bontásban

\section{Tanulmányi eredmények}

A képzésükre beiratkozók közül a képzésüket passzív félévvel kezdők (a mintában öszszesen 865 fö) 83,4\%-a később nem fejezte be képzését, szemben az aktív félévvel kezdők 35,3\%-ával. Ezen túl azok körében is kiemelt jelentősége van a későbbi passzív félévek számának, akik a legelső félévükben ténylegesen megkezdik képzésüket (2.ábra): a képzési idejük alatt kizárólag aktív félévekkel rendelkező hallgatók 19,3\%-a morzsolódott le, szemben az egy passzív félévvel rendelkezők 64,9\%-ával. Ez az arány a passzív félévek számának emelkedésével tovább romlik, jelezvén, hogy a passziválás egyike a legjelentősebb, tanulmányi rendszerből könnyen elérhető, lemorzsolódást valószínűsítő változóknak.

A felvételi pontszám és az első félév tanulmányi eredményességi mutatóinak kapcsolatát a sikeres képzészárással a 3. táblázat foglalja össze. Bár minden változó mentén szignifikánsan eltért a vizsgált két csoport, az eltérések nagyságát megvizsgálva jól látható, hogy az első félévben teljesített kreditek aránya különösen erős jelzőértékkel bír. A sikeresekre nem jellemző a teljesítetlen kurzusok nagy aránya, szemben a később lemorzsolódókkal, ami azt is jelezheti, hogy már az első félév végére jelentősen formálódik a képzés befejezésére irányuló motiváció.

Összességében a felvételi átlagpontszám, illetve a standardizált felvételi pontszám alacsonyabb volt a lemorzsolódottak körében, de az eltérés nagyságrendje (sőt időnként az iránya is) nagyon eltérő volt a különböző képzési területeken, és még inkább a különféle szakokon.

Szintén szignifikáns tényezőnek bizonyult a korábbi képzésfélbehagyás is (itt természetesen csak a vizsgált intézmény képzéseire vonatkozóan voltak adataink). Azon összesen 1640 hallgatóból, akik korábban már hagytak félbe képzést, összesen 64,6\% morzsolódott le a vizsgált képzéséről, szemben a lemorzsolódási tanulmányi előzménnyel nem rendelkezők (14266 fơ) 38,8\%-os lemorzsolódási arányával.

A lemorzsolódás-sikeresség kétértékű függőváltozója esélyhányadosainak becslésére épített bináris logisztikus regressziós magyarázó modell eredményét jelen tanulmány mellékletében rögzítettük. A modellalkotáshoz ENTER módszert alkalmaztunk. 
3. táblázat: Az ELTE-re 2012 és 2014 között alapképzésre felvett és képzésüket aktív félévvel kezdő hallgatók első féléves tanulmányi eredeményességi mutatói és felvételi pontszáma képzési sikeresség szerinti bontásban

\begin{tabular}{|c|c|c|c|c|c|c|}
\hline $\begin{array}{l}\text { Tanulmányi eredményességi } \\
\text { és felvételi mutatószámok }\end{array}$ & & $\begin{array}{l}\text { Lemorzso- } \\
\text { lódott }\end{array}$ & Sikeres & $t$ & $\mathrm{~d} f$ & szign. \\
\hline \multirow{3}{*}{$\begin{array}{l}\text { Első félévben teljesített } \\
\text { kreditek aránya }\end{array}$} & $N$ & 5389 & 9844 & \multirow{3}{*}{76,842} & \multirow{3}{*}{6251,152} & \multirow{3}{*}{$p<0,001$} \\
\hline & átlag & $53,8 \%$ & $93,8 \%$ & & & \\
\hline & $\mathrm{SD}$ & $36,71 \%$ & $13,94 \%$ & & & \\
\hline \multirow{3}{*}{ Első félév súlyozott átlag } & $N$ & 4394 & 9825 & \multirow{3}{*}{37,177} & \multirow{3}{*}{7182,267} & \multirow{3}{*}{$p<0,001$} \\
\hline & átlag & 3,41 & 3,88 & & & \\
\hline & $\mathrm{SD}$ & 0,725 & 0,599 & & & \\
\hline \multirow{3}{*}{$\begin{array}{l}\text { Első félév ismétlő vizsgáinak } \\
\text { a száma }\end{array}$} & $N$ & 5462 & 9815 & \multirow{3}{*}{13,975} & \multirow{3}{*}{9332,046} & \multirow{3}{*}{$p<0,001$} \\
\hline & átlag & 1,00 & 0,72 & & & \\
\hline & SD & 1,290 & 1,025 & & & \\
\hline \multirow{3}{*}{ Felvételi összpontszám } & $N$ & 3318 & 5561 & \multirow{3}{*}{12,426} & \multirow{3}{*}{7292,81} & \multirow{3}{*}{$p<0,001$} \\
\hline & átlag & 387,13 & 400,08 & & & \\
\hline & SD & 46,448 & 49,186 & & & \\
\hline \multirow{3}{*}{$\begin{array}{l}\text { Standardizált felvételi } \\
\text { összpontszám* }\end{array}$} & $N$ & 3309 & 5561 & \multirow{3}{*}{14,56} & \multirow{3}{*}{6761} & \multirow{3}{*}{$p<0,001$} \\
\hline & átlag & 0,9835 & 1,012 & & & \\
\hline & SD & 0,0941 & 0,0915 & & & \\
\hline
\end{tabular}

* A felvételi pontszámot tagozat, kezdési év, felvételi típus és finanszírozási forma bontásban standardizáltuk, 1 feletti érték jelzi, ha a hallgató felvételi pontszáma az adott felvételi évre, képzésre, a tagozatra, finanszírozási formára számított átlagos felvételi pontszámnál magasabb

A modell a lemorzsolódók csoportjába való kerülés esélyét mutatja a vizsgált változók mentén. A korábban individuálisan vizsgált háttérváltozók közül a modellben is jelentősnek bizonyult a képzési terület, a tagozat és finanszírozási forma hatása. A támogatáshoz kapcsolódó változók közül a szociális támogatás nem bizonyult szignifikánsnak, ugyanakkor a kollégium az egyik legjelentősebb tényezőnek bizonyult, a nem kollégisták tízszer nagyobb eséllyel sorolhatóak a lemorzsolódók közé $[\operatorname{Exp}(B)=10,4]$.

A szociodemográfiai háttérváltozók közül a nem szignifikánsnak bizonyult, a férfiak másfélszer nagyobb eséllyel tartoztak a lemorzsolódók közé, mint a nők $(\operatorname{Exp}(B)=$ 1,537), ugyanakkor az életkor és az állandó lakóhely településtípusa nem bizonyult szignifikáns változónak.

A tanulmányi mutatók közül az első féléves tanulmányi eredményességi változók szignifikánsnak bizonyultak, ugyanakkor a felvételi összpontszámnak nem volt szignifikáns kapcsolata a lemorzsolódó csoportba való kerülés esélyével. A korábban képzést még félbe nem hagyók fele akkora eséllyel morzsolódott le a vizsgált képzéséről, mint azok, akik már korábban is hagytak félbe képzést $[\operatorname{Exp}(B)=0,464]$. 


\title{
Pszichológiai változók szerepe a képzés folytatására irányuló szándékban
}

\author{
Módszer
}

\section{Résztvevők és eljárás}

A kutatás ezen szakaszában a pszichológiai sajátosságok lemorzsolódásban játszott szerepének feltárására kérdőíves vizsgálatot végeztünk, melynek eredményeit az egyes félévek végén a tanulmányi rendszerből elérhető adatokkal együtt elemeztünk. Minden olyan hallgatót felkértünk a részvételre, aki a 2018/2019-es őszi félévben új képzést kezdett a vizsgált felsőoktatási intézményben. A hallgatók a kérdőívet egy online felületen tölthették ki, és arra kértük őket, válaszaikat az aktuálisan megkezdett képzésükre vonatkoztassák. Az így gyüjtött adatok feldolgozásához az SPSS 21, illetve MPlus 8 programokat használtuk.

A vizsgálatban összesen 1871 személy adatait dolgoztuk fel (adattisztítás után), ez az egyetem egészére nézve 22,95\%-os kitöltési arányt jelent. A következőkben bemutatott elemzéseket egy ennél szűkebb mintán végeztük: azoknak a résztvevőknek a válaszain, akik a vizsgálat idején valamilyen alap-vagy osztatlan képzésen kezdtek tanulmányokat, ami összesen 1515 föt jelentett. Ezen vizsgálati személyek átlagéletkora 21,12 év (SD: 4,47), többségük nő (70,4\%), és alapképzésen tanul (81\%). A résztvevők túlnyomórészt nappali tagozatos hallgatók (90,0\%), 9,4\%-uk végzi levelező, 0,7\%-uk pedig esti tagozaton a tanulmányait. A válaszadók összesen kevesebb mint fele él a fơvárosban $(27,2 \%)$ vagy valamelyik megyeszékhelyen (15,9\%), a többiek más városból $(38,2 \%)$, községből $(18,2 \%)$ érkeztek, 8 fónek pedig (0,5\%) külföldön volt az állandó lakóhelye. Vizsgálatunk jelen szakaszában elemzéseinkhez súlyozatlan adatokat használtunk, eredményeink nem tekinthetők reprezentatívnak a sokaságra.

\section{Vizsgált változók és mérőeszközök}

Demográfiai és képzéssel kapcsolatos változók

A tanulmányi rendszerből elért vagy a kérdőívben szereplő demográfiai, illetve képzésre vonatkozó változók között olyan adatokat használtunk, mint a nem, életkor, állandó lakóhely, szak, képzési szint és munkarend. Ezenkívül minden tanulmányi félévre vonatkozóan rendelkezésünkre áll a hallgató képzésének aktuális állapota (aktív, diplomát szerzett vagy törölt), illetve az adott félév státusza (aktív vagy passzív), valamint az első két félév tanulmányi adatai (felvett és teljesített kreditek, tanulmányi átlagok).

Képzéssel való általános elégedettség

A képzéssel való elégedettség mérésére három állítást fogalmaztunk meg. $\mathrm{Pl}$.: „A képzést ajánlanám mások számára." A válaszadók az állítások tartalmával való egyetértésüket ötfokú Likert-skálán jelölhették. A skála megbízhatósága megfelelőnek bizonyult $(\alpha=$ 0,884).

A szak munkaeröpiaci értéke

A szak munkaerőpiaci értékével kapcsolatos vélemények feltárására szintén három állítást fogalmaztunk meg. Pl.: „Ezen a szakon olyan tudást sajátítok el, amit a munkámban 
majd jól tudok használni.” A válaszadók ötfokú Likert-skálán értékelték, hogy mennyire értenek egyet az egyes tételekkel. A vizsgált mintánkon a skála kiváló reliabilitásértéket mutatott $(0,885)$.

\section{Lemorzsolódási intenció}

A résztvevőket arra kértük, jelöljék egy háromfokú skálán, megfordult-e már a fejükben, hogy nem fejezik be a 2018 őszi félévben megkezdett képzésüket (1: nem, még sosem; 2: egyszer-kétszer, 3: igen, sokszor). A háromfokú skálát dichotómmá alakítva olyan változót kaptunk, amely alapján képzett csoportok közül az elsőbe azok a hallgatók kerültek, akik soha nem fontolgatták a tanulmányok abbahagyását, a másikba pedig azok, akiknek néhány alkalommal, vagy akár sokszor megfordult a fejében ez a gondolat.

4, táblázat: A kérdőíves felmérés során használt mérőeszközök

\begin{tabular}{|c|c|c|c|}
\hline Mérőeszköz & Alskála & $\begin{array}{l}\text { A tételek } \\
\text { száma }\end{array}$ & Cronbach- $\alpha$ \\
\hline \multirow{7}{*}{$\begin{array}{l}\text { Akadémiai Motivációk Skála-AMS-HUN } \\
\text { (Tótb-Király et al. 2017; Vallerand-Bissonnette } \\
\text { 1992) }\end{array}$} & $\begin{array}{l}\text { Tanulásra irányuló } \\
\text { intrinzik motiváció }\end{array}$ & 4 & 0,818 \\
\hline & $\begin{array}{l}\text { Dolgok elérésére vonat- } \\
\text { kozó intrinzik motiváció }\end{array}$ & 4 & 0,862 \\
\hline & $\begin{array}{l}\text { Stimuláció megélésére } \\
\text { vonatkozó intrinzik } \\
\text { motiváció }\end{array}$ & 4 & 0,857 \\
\hline & $\begin{array}{l}\text { Extrinzik motiváció, } \\
\text { identifikációs szabá- } \\
\text { lyozás }\end{array}$ & 4 & 0,767 \\
\hline & $\begin{array}{l}\text { Extrinzik motiváció, } \\
\text { introjektált szabályozás }\end{array}$ & 4 & 0,843 \\
\hline & $\begin{array}{l}\text { Extrinzik motiváció, } \\
\text { külső szabályozás }\end{array}$ & 4 & 0,829 \\
\hline & Amotiváció & 4 & 0,905 \\
\hline \multirow{4}{*}{$\begin{array}{l}\text { Módositott Célorientációs Kérdöív (Elliot- } \\
\text { Murayama 2008) }\end{array}$} & Elsajátítási-közelítő & 3 & 0,803 \\
\hline & Elsajátítási-elkerülő & 3 & 0,748 \\
\hline & Viszonyító-közelítő & 3 & 0,915 \\
\hline & Viszonyító-elkerülő & 3 & 0,944 \\
\hline \multirow{6}{*}{$\begin{array}{l}\text { Felsőoktatási Bennmaradás Kérdöív - FBK } \\
\text { (Czakó 2017) }\end{array}$} & Oktatói támogatás & 3 & 0,849 \\
\hline & $\begin{array}{l}\text { Saját teljesítménnyel } \\
\text { kapcsolatos elvárások }\end{array}$ & 3 & 0,839 \\
\hline & Elvárások átláthatósága & 3 & 0,860 \\
\hline & Társas bevonódás & 3 & 0,803 \\
\hline & Lemorzsolódási szándék & 3 & 0,899 \\
\hline & Tanulmányi bevonódás & 3 & 0,862 \\
\hline
\end{tabular}


4. táblázat: (folyt.)

\begin{tabular}{llll}
\hline Mérőeszköz & \multicolumn{1}{c}{ Alskála } & $\begin{array}{c}\text { A tételek } \\
\text { száma }\end{array}$ & Cronbach- $\alpha$ \\
\hline $\begin{array}{l}\text { Én-hatékonyság Kérdöív - SEQ (Gaumer } \\
\text { Erickson et al. 2016) }\end{array}$ & 13 & 0,873 \\
\hline $\begin{array}{l}\text { Észlelt Tanulási Kompetenciák Skála } \\
\text { (Williams-Freedman-Deci 1998) }\end{array}$ & 4 & 0,792 \\
\hline $\begin{array}{l}\text { Élettel Való Elégedettség Skála-SWLS (Diener } \\
\text { et al. 1985; Makra-Farkas-Orosz 2012) }\end{array}$ & Szorongás & 5 & 0,848 \\
\hline & Depresszió & 6 & 0,834 \\
& $\begin{array}{l}\text { Ellenségesség } \\
\text { Derogatis Rövid Tünetlista-BSI (Derogatis }\end{array}$ & 6 & 0,875 \\
2001; Unoka et al. 2004) & $\begin{array}{l}\text { Interperszonális érzé- } \\
\text { kenység }\end{array}$ & 5 & 0,794 \\
\cline { 2 - 5 } & Kényszer & 6 & 0,760 \\
\hline
\end{tabular}

Pszichológiai jellemzökre vonatkozó kérdöivek

A már bemutatott változókra vonatkozó kérdések megválaszolásán kívül a résztvevők egy standardizált mérőeszközökből álló kérdőívcsomagot is kitöltöttek. Ezek olyan pszichológiai sajátosságok mérését célozták meg, mint az egyetemi tanulmányok folytatása mögött meghúzódó motivációk, célorientációk, a felsőoktatásban való bennmaradás tényezői, én-hatékonyság és észlelt tanulási kompetenciák, élettel való elégedettség és pszichés tünetek. Az ezeknek a változóknak a vizsgálatára alkalmazott kérdőívek jellemzőit a 4. táblázat foglalja össze.

\section{Eredmények}

\section{A lemorzsolódási szándékot előrejelző változók modellje}

Kutatásaink fő célja azoknak a tényezőknek az azonosítása, melyek segítségével már a képzés korai szakaszában előrejelezhető, mely hallgatók veszélyeztetettek a lemorzsolódás szempontjából. Mivel a kérdőíves vizsgálatunkban részt vevő diákok körében az adatfelvétel idején (a képzés első féléve alatt) még nem beszélhetünk tényleges lemorzsolódásról, a vizsgálatunk legfontosabb kimeneti változója kezdetben a lemorzsolódási intenció volt, amelyet Felsőoktatási Bennmaradási Kérdőív „lemorzsolódási szándék” alskálája segítségével mértünk. A következőkben a lemorzsolódási szándékot előrejelző pszichológiai változók lineáris regresszióelemzéseken alapuló útmodelljét mutatjuk be (3. ábra). A modell létrehozásakor a szakirodalmi előzményekből, illetve feltáró célú (többségében korrelációs) alapelemzéseink eredményeiből indultunk ki.

Korábbi vizsgálataink eredményeihez hasonlóan (Czakó-Bolló 2017) most is azt találtuk, hogy a lemorzsolódási szándékot közvetlenül az amotiváció, vagyis a kiábrándultság, a tanulás értelmének megkérdőjelezése jelzi előre leginkább. Fontos kérdés azonban, hogy milyen tényezők állnak ennek hátterében. Elemzéseink azt mutatják, hogy ebből a szempontból leginkább a tanulmányi bevonódás (amely a lemorzsolódási szándék köz- 


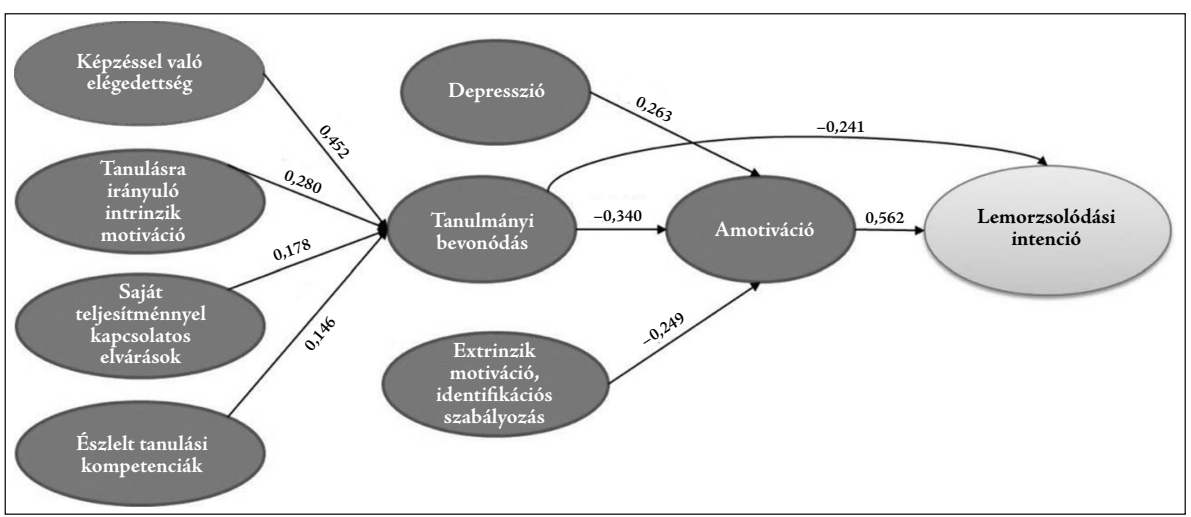

3. ábra: A lemorzsolódási szándékot előrejelző változók modellje. (Az ábrán csak a szignifikáns eredményeket jelöltük, a nyilakon a standardizált regressziós együtthatókat tüntettük fel. Útmodellünket az MPlus 8 program segítségével vizsgáltuk.)

vetlen prediktora is), valamint a pszichés tünetek közül a depresszió, illetve a motivációs skálák közül az identifikációs szabályozás extrinzik motivációja bír nagy jelentőséggel. Vagyis a depressziós tünetek súlyossága és gyakorisága, illetve az, hogy a hallgató kevéssé méri fel az egyetemi tanulmányok folytatásának fontosságát (például későbbi munkavállalása szempontjából), illetve a tanulmányokkal kapcsolatos bevonódás, elhivatottság alacsony szintje valószínűsíti az amotiváció, ez pedig a lemorzsolódási szándék magasabb mértékét. A modell alapján a tanulmányi bevonódás, azaz annak érzése, hogy a hallgató szívesen foglalkozik egyetemi tanulmányaival, leginkább azzal függ össze, hogy mennyire elégedett a képzésével, mennyire fontos számára a tanulás, a felfedezés öröme (tanulásra irányuló intrinzik motiváció), milyen elvárásokat támaszt saját magával szemben, illetve mennyire érzi úgy, hogy birtokában van a képzés elvégzéséhez szükséges készségeknek (észlelt tanulási kompetenciák).

A lemorzsolódási szándékot előrejelző változók modelljére vonatkozó illeszkedési mutatók többsége megfelelőnek bizonyult: $\mathrm{CFI}=0,952$; TLI $=0,916 ; \chi^{2} / \mathrm{d} f=139,544 / 12$; RMSEA = 0,098; SRMR = 0,032 (Hu-Bentler 1999). A modell segítségével a lemorzsolódási szándék varianciájának 51,4\%-át tudtuk magyarázni, ami viszonylag magas arány, azonban további, nem vizsgált változók lehetséges szerepére utal (természetesen nem feltételezhetjük, hogy a képzés abbahagyására irányuló intenciók hátterében kizárólag pszichológiai tényezők húzódnak meg).

A képzés félbehagyására irányuló intenció és a tényleges lemorzsolódás közötti összefüggés

A lemorzsolódási szándékot kimeneti változóként használó elemzéseink során azt feltételeztük, hogy ez valamilyen mértékben megfeleltethető a hallgató későbbiekben ténylegesen bekövetkező lemorzsolódásának. Ezért is fontos vizsgálni, hogy ez a két tényező ténylegesen milyen kapcsolatban áll egymással. Ebből a célból a már bemutatott, lemorzsolódási intencióra vonatkozó háromfokú skálán adott válaszaik alapján osztottuk két csoportba a résztvevőket (megfordult már a fejében, hogy nem fogja befejezni a megkezdett képzést vagy sosem gondolt még erre), majd a képzésben maradó és a lemorzsolódó 


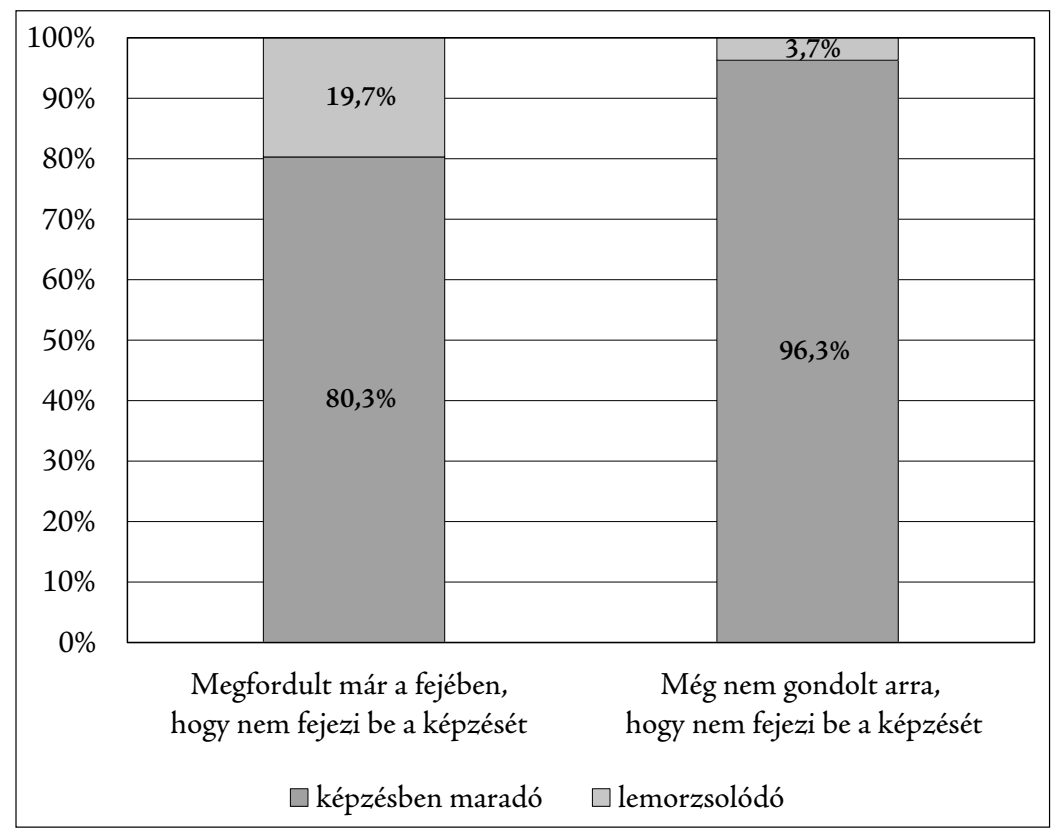

4. ábra: A harmadik félévük kezdetére már lemorzsolódott és az ekkor még képzésüket folytató hallgatók aránya a lemorzsolódási intenció alapján képzett csoportokban

hallgatók százalékos arányát hasonlítottuk össze a két csoportban khi-négyzet próba használatával. (Lemorzsolódónak tekintettük azokat is, akik a képzésük 2. és 3. félévében is passzív státuszúak voltak, illetve a képzésben maradók közé soroltuk azokat, akik ez alatt az idő alatt már diplomát szereztek.)

A két csoport közötti különbség szignifikánsnak bizonyult $\left[\chi^{2}(1)=96,980 ; p<\right.$ 0,001]. Míg azoknak a hallgatóknak a körében, akiknek az első félévben saját bevallásuk szerint nem fordult meg a fejében, hogy a diplomaszerzést megelőzően abbahagyják a megkezdett képzésüket, csak 3,7\% volt a második félév végére ténylegesen lemorzsolódók aránya, a másik csoportban ez az arány ennek több mint az ötszöröse: 19,7\% (4. ábra). Ez azt is jelenti, hogy a lemorzsolódást fontolgató diákok döntő többsége egyelőre folytatja a képzését, a harmadik félév kezdetéig lemorzsolódók száma a két csoportban összesen is viszonylag alacsony: 143 fö. Ugyanakkor eredményeink arra utalnak, hogy azok, akik magasabb lemorzsolódási intencióról számolnak be, valóban nagyobb eséllyel hagyják abba a megkezdett képzést.

\section{A korán lemorzsolódó és a képzésen bennmaradó hallgatók pszichológiai sajátosságai}

Kutatásunk további fontos célkitüzése volt azoknak a pszichológiai sajátosságoknak a meghatározása, amelyek mentén a képzés korai szakaszában lemorzsolódott és a képzésben maradó, illetve diplomát szerzett hallgatók különböznek. A továbbiakban az erre vonatkozó elemzéseink eredményeit mutatjuk be. 
Motiváció: A vizsgált motivációs skálákra vonatkozó eredményeket az 5. táblázatban foglaltuk össze. A külső-belső motivációs tényezőkre, illetve célorientációkra vonatkozó skálák közül az AMS „Extrinzik motiváció, külső szabályozás” dimenziója kivételével

5. táblázat: A motivációs skálák átlagpontszámai a lemorzsolódó és képzésben maradó hallgatók körében

\begin{tabular}{|c|c|c|c|c|c|c|c|}
\hline & & & $N$ & Átlag & Szórás & $\begin{array}{c}\text { Mann- } \\
\text { Whitney } U\end{array}$ & $p$ \\
\hline \multirow{14}{*}{ 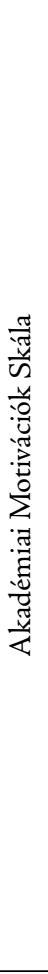 } & \multirow{2}{*}{$\begin{array}{l}\text { Tanulásra irányuló } \\
\text { intrinzik motiváció }\end{array}$} & $\begin{array}{l}\text { képzésben } \\
\text { maradó }\end{array}$ & 1293 & 5,44 & 1,16 & \multirow[t]{2}{*}{74079,00} & \multirow[t]{2}{*}{0,000} \\
\hline & & lemorzsolódó & 143 & 4,98 & 1,37 & & \\
\hline & \multirow{2}{*}{$\begin{array}{l}\text { Dolgok elérésére } \\
\text { vonatkozó intrinzik } \\
\text { motiváció }\end{array}$} & $\begin{array}{l}\text { képzésben } \\
\text { maradó }\end{array}$ & 1293 & 4,77 & 1,38 & \multirow[t]{2}{*}{69248,00} & \multirow[t]{2}{*}{0,000} \\
\hline & & lemorzsolódó & 143 & 4,10 & 1,56 & & \\
\hline & \multirow{2}{*}{$\begin{array}{l}\text { Stimuláció megélé- } \\
\text { sére vonatkozó } \\
\text { intrinzik motiváció }\end{array}$} & $\begin{array}{l}\text { képzésben } \\
\text { maradó }\end{array}$ & 1293 & 4,19 & 1,48 & \multirow[t]{2}{*}{78881,50} & \multirow[t]{2}{*}{0,004} \\
\hline & & lemorzsolódó & 143 & 3,81 & 1,42 & & \\
\hline & \multirow{2}{*}{$\begin{array}{l}\text { Extrinzik motiváció, } \\
\text { identifikációs szabá- } \\
\text { lyozás }\end{array}$} & $\begin{array}{l}\text { képzésben } \\
\text { maradó }\end{array}$ & 1293 & 5,70 & 1,07 & \multirow[t]{2}{*}{73263,00} & \multirow[t]{2}{*}{0,000} \\
\hline & & lemorzsolódó & 143 & 5,15 & 1,48 & & \\
\hline & \multirow{2}{*}{$\begin{array}{l}\text { Extrinzik motiváció, } \\
\text { introjektált szabá- } \\
\text { lyozás }\end{array}$} & $\begin{array}{l}\text { képzésben } \\
\text { maradó }\end{array}$ & 1293 & 4,96 & 1,50 & \multirow{2}{*}{77963,50} & \multirow[t]{2}{*}{0,002} \\
\hline & & lemorzsolódó & 143 & 4,45 & 1,77 & & \\
\hline & \multirow{2}{*}{$\begin{array}{l}\text { Extrinzik motiváció, } \\
\text { külső szabályozás }\end{array}$} & $\begin{array}{l}\text { képzésben } \\
\text { maradó }\end{array}$ & 1293 & 5,25 & 1,39 & \multirow{2}{*}{84618,50} & \multirow[t]{2}{*}{0,095} \\
\hline & & lemorzsolódó & 143 & 5,02 & 1,53 & & \\
\hline & \multirow[t]{2}{*}{ Amotiváció } & $\begin{array}{l}\text { képzésben } \\
\text { maradó }\end{array}$ & 1293 & 1,49 & 0,97 & \multirow[t]{2}{*}{55339,50} & \multirow[t]{2}{*}{0,000} \\
\hline & & lemorzsolódó & 143 & 2,51 & 1,80 & & \\
\hline \multirow{8}{*}{ 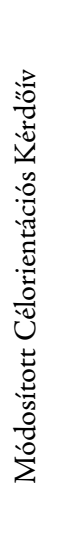 } & \multirow[t]{2}{*}{ Elsajátítási-közelítő } & $\begin{array}{l}\text { képzésben } \\
\text { maradó }\end{array}$ & 1275 & 4,21 & 0,71 & \multirow[t]{2}{*}{69267,00} & \multirow[t]{2}{*}{0,000} \\
\hline & & lemorzsolódó & 142 & 3,87 & 0,87 & & \\
\hline & \multirow[t]{2}{*}{ Elsajátítási-elkerülő } & $\begin{array}{l}\text { képzésben } \\
\text { maradó }\end{array}$ & 1275 & 3,75 & 0,86 & \multirow{2}{*}{74032,00} & \multirow[t]{2}{*}{0,000} \\
\hline & & lemorzsolódó & 142 & 3,46 & 0,98 & & \\
\hline & \multirow[t]{2}{*}{ Viszonyító-közelítő } & $\begin{array}{l}\text { képzésben } \\
\text { maradó }\end{array}$ & 1275 & 3,38 & 1,12 & \multirow[t]{2}{*}{77513,50} & \multirow[t]{2}{*}{0,005} \\
\hline & & lemorzsolódó & 142 & 3,07 & 1,24 & & \\
\hline & \multirow[t]{2}{*}{ Viszonyító-elkerülő } & $\begin{array}{l}\text { képzésben } \\
\text { maradó }\end{array}$ & 1275 & 3,71 & 1,14 & \multirow[t]{2}{*}{79607,00} & 0,017 \\
\hline & & lemorzsolódó & 142 & 3,43 & 1,27 & & \\
\hline
\end{tabular}


mindegyiken szignifikáns különbséget találtunk a két csoport között, azaz a tanuláshoz kapcsolódó jutalmak (mint például a jövőbeli anyagi biztonság) motiváló szerepe az egyetlen, amely azonos jelentőséggel bír a lemorzsolódó és a képzést folytató vagy elvégző diákok körében. Ezenkívül szinte minden tényező tekintetében magasabb a képzésben maradó hallgatók átlaga, kivéve az „Amotiváció” skálát. Összességében megállapíthatjuk, hogy a korán lemorzsolódó vizsgálati személyekre nem a motivációs tényezők bizonyos fajtái (például jellegzetes célorientáció) vagy az ezekből kialakult mintázat jellemző elsősorban, hanem a motiváció általánosan alacsonyabb mértéke, illetve az amotiváció magasabb szintje.

Szubjektiv jóllét és pszichés tünetek: Az élettel való elégedettségre és a pszichés tünetek gyakoriságára, súlyosságára vonatkozóan minden skálán szignifikáns eltérés van a hallgatók két csoportja között. A lemorzsolódó résztvevők alacsonyabb élettel való elégedettségről $(U=71460,50 ; p<0,01)$, de több depressziós $(U=70678,50 ; p<0,01)$, szorongásos $(U=72880,00 ; p<0,01)$ és kényszeres tünetről $(U=76106,50 ; p<0,01)$, valamint magasabb interperszonális érzékenységről $(U=78289,00 ; p<0,05)$ és ellenségességről $(U=76675,50 ; p<0,05)$ számolnak be.

A képzéssel, tanulmányokkal kapcsolatos vélemények, attitüdök: Mindkét saját képzéssel kapcsolatos szubjektív véleményre vonatkozó változó tekintetében szignifikáns a különbség a két csoport között. A lemorzsolódó hallgatók már az első félévben kevésbé elégedettek az éppen megkezdett képzésükkel $(U=37470,500 ; p<0,01)$, illetve arról is kevésbé vélekednek pozitívan, hogy az itt megszerzett tudást mennyire tudják a későbbiekben használni a munkaerőpiacon $(U=36742,000 ; p<0,01)$. Ugyanakkor a képzésben maradó társaikhoz képest kevésbé érzik úgy, hogy birtokában vannak az egyetemi képzésük elvégzéséhez szükséges készségeknek (észlelt tanulási kompetenciák - $U=56330,00$; $p<0,01)$, ami összefügghet azzal, hogy általános én-hatékonyságuk is alacsonyabb $(U=$ $73787,50 ; p<0,01)$.

\section{Korlátok}

Bár az első vizsgálat három teljes évfolyam adatainak elemzését tette lehetővé, de a gyakori képzési időn való túlfutásra való tekintettel ahhoz, hogy tényleges lemorzsolódási adatokat láthassunk, időben viszonylag távoli évfolyamokat (2012-2014) vizsgáltunk. A tanulmányi rendszerben sok esetben találtunk ellentmondásokat az egy hallgatóra vonatkozóan rögzített adatokban, melyeket az elérhető többi adat segítségével igyekeztünk a lehetö legpontosabban feloldani.

A második vizsgálatban az eredmények generalizálhatóságát korlátozza, hogy kényelmi adatfelvételt alkalmaztunk, a válaszadási hajlandóság mögött pedig feltételezhető valamilyen általunk nem ismert szisztematikus hiba is, illetve feltételezhető, hogy a legkevésbé involvált, motivált hallgatókat csak kisebb arányban értük el. Ezt az adatbázis későbbi súlyozása valamelyest majd korrigálhatja, de tekintettel arra, hogy ez egy folyamatban levő kutatás, és a legfrissebb adatok jelen tanulmány írásakor még alig egy hete álltak rendelkezésünkre, ez az elemzés ezen fázisában még nem történt meg.

Az eredményekből nem lehet ok-okozatra vonatkozó következtetéseket levonni, bár összefüggéseket látunk, nem mindig világos, hogy a lemorzsolódási szándékot jelző (eset- 
leg később ténylegesen lemorzsolódó), illetve az azt nem jelző hallgatók a képzésre történő belépés időpontjában miben különböztek egymástól, és mennyire az első egyetemi hónapjaik tapasztalatai tükröződnek már válaszaikban. A jelen tanulmányban bemutatott vizsgálatok nem tartalmaztak kompetenciaméréseket, egyedül a felvételi pontszámokból lehet bármilyen megközelítő következtetést tenni az egyetemi képzést megelőző tanulmányi eredményességre. Az egyes képzések közötti különbségeket megfelelő mintanagyság hiányában nem tudtuk kezelni, holott a hallgatói tapasztalatok, élmények a különböző képzéseken szignifikánsan eltérhetnek.

\section{Következtetések}

Vizsgálataink eredményei szerint a hallgatók bemeneti jellemzői közül többnek a jelentősége összességében kisebb volt, mint azt elözetesen gondoltuk. Ilyen volt a lakóhely településhierarchiában elfoglalt pozíciója vagy az életkor, illetve a felvételi pontszám lemorzsolódással való kapcsolata, ami a bináris logisztikus modellben összességében nem bizonyult szignifikáns változónak. Ez a különböző tényezők egymásra hatásával magyarázható, és még további elemzések szükségességére hívja fel a figyelmet.

Fontos változónak bizonyult a nem (a természettudományi képzések kivételével, ahol a férfiak és nők sikerességi aránya közti különbség nem szignifikáns), valamint az adott képzés alapvető jellemzői: a tagozat, a finanszírozási forma és a képzési terület. Összességében sikeresebbek a hagyományos hallgatói csoportok, vagyis azok, akik képzésüket államilag támogatott formában, nappali tagozaton kezdik meg. Jelentős tényezőnek bizonyult - az eddigi elemzések fényében - a támogatás jelenléte, a kollégiumi elhelyezés, illetve kisebb mértékben a szociális támogatás. A lemorzsolódási szándék szempontjából meghatározó jelentőséggel bír az is, hogy a későbbi életlehetőségek szempontjából miként percipiálják a válaszadók a választott képzésüket.

A tanulmányi rendszerből kinyerhető adatokból megállapítható, hogy a több félévet is érintő passziválás szoros összefüggést mutat a későbbi lemorzsolódással, ugyanakkor indokolt feltételezni, hogy a passziválásra időnként már az egyetemen szerzett személyes tapasztalatok következtében kerül sor. Fontos tényezőnek tünik az első félév tanulmányi eredményessége (a teljesített kreditek aránya és a súlyozott tanulmányi átlag), de e tekintetben is csak óvatos következtetések fogalmazhatóak meg, mivel a motivációk, a képzés értékének percepciója és az első féléves tanulmányi eredményességmutatók közti ok-okozati kapcsolat a rendelkezésre álló adatok alapján nem határozható meg. Az alacsony tanulmányi átlag és teljesített kreditarány éppen annyira lehet következménye, illetve oka az amotivációnak és a képzés be nem fejezésére irányuló szándéknak.

Reményeink szerint a lemorzsolódás jelenségének jobb megértését nagyban segítheti, hogy ez a vizsgálat lehetőséget teremt arra is, hogy a pszichológiai jellemzők és a tanulmányi életút jellegzetességeit egyidejüleg tudjuk vizsgálni. Eddigi elemzéseink arra mutatnak, hogy a lemorzsolódási szándék szempontjából a pszichológiai változók jelentősége nagy, ugyanakkor fontos megállapítani, hogy az elemzésbe vont változók, az útmodell tanúsága szerint, összességében csak a variancia felét tudták magyarázni. Jelentős a motiváció és motiválatlanság súlya, ami úgy tűnik, már a képzés első hónapjaiban megjelenik. További elemzések szükségesek azon kérdés megválaszolásához, hogy mely tényezők befolyásolják leginkább a hallgatók motivációs „állapotát”. Mindez felhívja a figyelmet arra, hogy az egyetemi élet első néhány hónapja során szerzett tapasztalatok, továbbá 
a tanulmányi és társas bevonódás megélt mértéke kiemelkedő fontosságú a tanulmányi sikeresség szempontjából.

$\mathrm{A} z$ eredményeinkből az is kitűnik, hogy a lemorzsolódók nagyobb része nem egyszerűen pályakorrekciót hajt végre, összességében rosszabbul érzik magukat, mint a sikeresek. Bár a különbségek nem nagyok, de következetesen szignifikánsak, ill. irányuk is állandó: mindig a lemorzsolódóknál jelentkezik több pszichológiai tünet, személyes jóllétüket alacsonyabbra értékelik, továbbá a korábban lemorzsolódók új képzésüket is nagyobb arányban hagyják félbe.

Összességében az eredmények az egyetemen tapasztaltak kiemelkedő jelentőségét jelzik a lemorzsolódási szándék szempontjából (feltételezhetően akár a bemeneti jellemzőkkel történő összehasonlításban is, de e tekintetben csak óvatos feltételezéseink lehetnek, mivel nem végeztünk kompetenciaméréseket, vagyis ezen a területen még további vizsgálódásokra van szükség).

A fentiekben felsorolt tényezőket, s kiváltképpen az azok között sejthető interakciókat a lemorzsolódást csökkentő intervenciók tervezésénél is figyelembe kell venni. Kiemelten szükséges figyelni a passziválókra, illetve az intervenciókra kevésbé fogékony és nehezebben elérhető, nem hagyományos hallgatói csoportokra. Kulcstényező lehet a motiváció megsegítése, illetve a bevonódás, elköteleződés kialakulásának támogatása.

\section{IRODALOM}

2011. évi CCIV. törvény a nemzeti felsőoktatásról. Pub. L. No. CCIV. (2011).

Bean, J. P. (1980) Dropouts and Turnover: The Synthesis and Test of a Causal Model of Student Attrition. Research in Higher Education, Vol. 12. No. 2. pp. 155-187.

Berger, J. B. \& Braxton, J. M. (1998) Revising Tinto's Interactionalist Theory of Student Departure through Theory Elaboration: Examining the Role of Organizational Attributes in the Persistence Process. Research in Higher Education, Vol. 39. No. 2. pp. 103-119. https://doi.org/10.1023/A:1018760513769

Braxton, J. M., Doyle, W. R., Hartley III, H. V., Hirschy, A. S., Jones, W. A. \& McLendon, M. K. (2014) Rethinking College Student Retention (1 edition). San Francisco (CA), Jossey-Bass.

Cabrera, A. F., Nora, A. \& Castaneda, M. B. (1992) The Role of Finances in the Persistence Process: A Structural Model. Research in Higher Education, Vol. 33. No. 5. pp. 571-593. https://doi.org/10.1007/BF00973759

Czakó A. (2017) A felsőoktatási lemorzsolódási intenciók pszichológiai háttértényezői. https://doi.org/10.15476/ELTE.2017.188 [Letöltve: 2019. 10. 17.]

Czaкó A. \& Bolló H. (2017) A lemorzsolódással veszélyeztetett hallgatók jellemzői. Előadás: Személyes tér - közös világ: A Magyar Pszichológiai Társaság XXVI. Országos Tudományos Nagygyülése, Szeged.

Davidson, C. \& Wilson, K. (2013) Reassessing Tinto's Concepts of Social and Academic Integration in Student Retention. Journal of College Student Retention: Research, Theory $\mathcal{E}$ Practice, Vol. 15. No.3. pp. 329-346. https://doi.org/10.2190/CS.15.3.b

Derogatis, L. R. (2001) Brief Symptom Inventory 18 (BSI-18): Administration, Scoring, and Procedures Manual. Bloomington (MN), Pearson.

Diener, E., Emmons, R. A., Larsen, R. L. \& Griffin, S. (1985) The Satisfaction with Life Scale. Journal of Personality Assessment, Vol. 49. No. 1. pp. 71-75. 
CZAKÓ ANDREA - NÉMETH LILLA - FELVINCZI KATALINः A FELSŐFOKÚ KÉPZÉS BEFEJEZÉSÉRE...

Elliot, A. J. \& Murayama, K. (2008) On the Measurement of Achievement Goals: Critique, Illustration, and Application. Journal of Educational Psychology, Vol. 100. No. 3. pp. 613-628. https://doi.org/10.1037/0022-0663.100.3.613

Gaumer Erickson, A. S., Soukup, J. H., Noonan, P. M. \& McGurn, L. (2016) Self-Efficacy Questionnaire. http://www.researchcollaboration.org/uploads/SelfEfficacyQuestionnaireInfo.pdf [Letöltve: 2019. 10. 17.]

Hu, L. \& Bentler, P. M. (1999) Cutoff Criteria for Fit Indexes in Covariance Structure Analysis: Conventional Criteria Versus New Alternatives. Structural Equation Modeling: A Multidisciplinary Journal, Vol. 6. No. 1. pp. 1-55. https://doi. org/10.1080/10705519909540118

Makra E., Farkas D. \& Orosz G. (2012) The Validation of Hungarian Work-Family Conflict Questionnaire and the Analysis of Predictors of Work-Family Balance. Magyar Pszichológiai Szemle, Vol. 67. No. 3. pp. 491-518. https://doi.org/10.1556/ MPSzle.67.2012.3.5

OECD (2017) Indicator C3 Who Is Expected to Enter Tertiary Education? In: OECD, Education at a Glance 2017. pp. 272-285. https://doi.org/10.1787/eag-2017-25-en

Reason, R. D., Terenzini, P. T. \& Domingo, R. J. (2006) First Things First: Developing Academic Competence in the First Year of College. Research in Higher Education, Vol. 47. No. 2. pp. 149-175. https://doi.org/10.1007/s11162-005-8884-4

STÉger C. (2015) A hatékonyság, a lemorzsolódás és a módszertan összefüggései a felsőoktatásban. Előadás: Záró szakmai konferencia Szombathelyen - TÂMOP4.1.2.B.2-13/1-2013-0003, Szombathely. https://sek.videotorium.hu/hu/ recordings/10940/a-hatekonysag-a-lemorzsolodas-es-a-modszertan-osszefuggesei-afelsooktatasban [Letöltve: 2019. 10. 17.]

Stéger C. \& DemcsáKné Ódor Z. (2015) Lemorzsolódásról a FIR adatai alapján. Oktatási Hivatal - Felsőoktatási Főosztály.

Tinto, V. (1975) Dropout from Higher Education: A Theoretical Synthesis of Recent Research. Review of Educational Research, Vol. 45. No. 1. pp. 89-125. https://doi. org/10.3102/00346543045001089

Tóth-Király I., Orosz G., Dombi E., Jagodics B., Farkas D. \& Amoura, C. (2017) Cross-Cultural Comparative Examination of the Academic Motivation Scale Using Exploratory Structural Equation Modeling. Personality and Individual Differences, Vol. 106. pp. 130-135. https://doi.org/10.1016/j.paid.2016.10.048

Unoka Z., Rózsa S., Kő N., Kállai J., Fábián Á. \& Simon L. (2004) A Derogatis-féle Tünetlista hazai alkalmazásával szerzett tapasztalatok. Psychiatria Hungarica, Vol. 3. No. 3. pp. 28-35.

Vallerand, R. J. \& Bissonnette, R. (1992) Intrinsic, Extrinsic, and Amotivational Styles as Predictors of Behavior: A Prospective Study. Journal of Personality, Vol. 60. No. 3. pp. 599-620. https://doi.org/10.1111/j.1467-6494.1992.tb00922.x

Vallerand, R. J., Fortier, M. S. \& Guay, F. (1997) Self-determination and Persistence in a Real-life Setting: Toward a Motivational Model of High School Dropout. Journal of Personality and Social Psychology, Vol. 72. No. 5. pp. 1161-1176. https://doi. org/10.1037/0022-3514.72.5.1161

Williams, G. C., Freedman, Z. R. \& Deci, E. L. (1998) Supporting Autonomy to Motivate Patients with Diabetes for Glucose Control. Diabetes Care, Vol. 21. No. 10. pp. 1644-1651. https://doi.org/10.2337/diacare.21.10.1644 


\section{MELLÉKLET}

A 2012 és 2014 között alapképzésre felvett hallgatók képzési sikerességének bináris logisztikus modellje

\begin{tabular}{|c|c|c|c|c|c|c|}
\hline Magyarázó változók & $\operatorname{Exp}(B)$ & $B$ & S.E. & Wald & $\mathrm{d} f$ & Sig. \\
\hline Tagozat (ref.: nappali) & & & & 22,667 & 2 & 0,000 \\
\hline Esti & $0,508^{*}$ & $-0,678$ & 0,339 & 4,007 & 1 & 0,045 \\
\hline Levelező & $2,021^{* * *}$ & 0,704 & 0,174 & 16,374 & 1 & 0,000 \\
\hline \multicolumn{2}{|l|}{ Képzési terület (ref.: Bölcsészettudomány) } & & & 167,814 & 7 & 0,000 \\
\hline Gazdaságtudományok & 0,462 & $-0,771$ & 0,610 & 1,599 & 1 & 0,206 \\
\hline Informatika & $2,494^{* * *}$ & 0,914 & 0,143 & 41,045 & 1 & 0,000 \\
\hline Jogi & $0,063^{* * *}$ & $-2,759$ & 0,283 & 94,751 & 1 & 0,000 \\
\hline Pedagógusképzés & $0,637^{\star *}$ & $-0,450$ & 0,132 & 11,728 & 1 & 0,001 \\
\hline Sporttudomány & $0,475^{\star *}$ & $-0,744$ & 0,232 & 10,331 & 1 & 0,001 \\
\hline Társadalomtudomány & $0,572^{* * *}$ & $-0,559$ & 0,134 & 17,519 & 1 & 0,000 \\
\hline Természettudomány & 1,21 & 0,191 & 0,102 & 3,468 & 1 & 0,063 \\
\hline Lakóhely típusa (ref.: főváros) & & & & 7,353 & 4 & 0,118 \\
\hline község & 0,823 & $-0,194$ & 0,102 & 3,658 & 1 & 0,056 \\
\hline külföld & 0,688 & $-0,375$ & 0,249 & 2,255 & 1 & 0,133 \\
\hline megyeszékhely & $0,806^{*}$ & $-0,215$ & 0,102 & 4,471 & 1 & 0,034 \\
\hline város & 0,854 & $-0,158$ & 0,088 & 3,191 & 1 & 0,074 \\
\hline Nem (ref.: nő) & $1,537^{* * *}$ & 0,430 & 0,082 & 27,764 & 1 & 0,000 \\
\hline $\begin{array}{l}\text { Első félév finanszírozási forma } \\
\text { (ref.: államilag támogatott) }\end{array}$ & $1,461^{* *}$ & 0,379 & 0,121 & 9,829 & 1 & 0,002 \\
\hline $\begin{array}{l}\text { Első félév szociális ösztöndíj } \\
\text { (ref.: kapott) }\end{array}$ & 0,872 & $-0,136$ & 0,088 & 2,385 & 1 & 0,122 \\
\hline Kollégista volt-e? (ref.: igen) & $10,4^{\star * *}$ & 2,342 & 0,105 & 499,393 & 1 & 0,000 \\
\hline Életkor & 0,998 & $-0,002$ & 0,009 & 0,027 & 1 & 0,870 \\
\hline $\begin{array}{l}\text { Első félévben a teljesített kreditek } \\
\text { aránya }\end{array}$ & $0,929^{* * *}$ & $-0,074$ & 0,003 & 858,196 & 1 & 0,000 \\
\hline Első félév súlyozott átlaga & $0,465^{\star * *}$ & $-0,765$ & 0,073 & 110,929 & 1 & 0,000 \\
\hline Első félévben az ismétlő vizsgák száma & $1,159^{\star * *}$ & 0,147 & 0,033 & 19,826 & 1 & 0,000 \\
\hline Felvételi összpontszám & 0,999 & $-0,001$ & 0,001 & 2,442 & 1 & 0,118 \\
\hline Korábban morzsolódott-e le (ref.: igen) & $0,464^{\star * *}$ & $-0,768$ & 0,135 & 32,439 & 1 & 0,000 \\
\hline
\end{tabular}

Nagelkerke-féle pszeudó- $R^{2}$ (magyarázóerö): $57 \%$; $p<0,05 ;{ }^{* *} p<0,01 ;{ }^{* * *} p<0,001$

A cikk a Creative Commons Attribution 4.0 International License (https://creativecommons.org/licenses/ by/4.0/) feltételei szerint publikált Open Access közlemény, melynek szellemében a cikk bármilyen médiumban szabadon felhasználható, megosztható és újraközölhető, feltéve, hogy az eredeti szerző és a közlés helye, illetve a CC License linkje és az esetlegesen végrehajtott módosítások feltüntetésre kerülnek. (SID_1) 